\title{
Factors Affecting Solar Photovoltaic Power Output at Particular Location and Cost Estimation
}

\section{Nakkela $\mathrm{H}^{*}$}

Andhra University College of Engineering, Visakhapatnam, Andhra Pradesh, India

\begin{abstract}
Fossil fuels like coal, gas, diesel etc., used for generate electrical energy are in exhaust stage and causes pollution. This necessitates alternative sources of fuels which are renewable and non-pollutant like wind, solar, tidal to generate electrical energy. These renewable fuels cannot be supplied to generate power as required like conventional fuels, as they are naturally available and depends on environmental conditions. Hence they have to be efficiently utilized when they are available. Solar energy is the electromagnetic waves in the form of light which contains packets of energy known as photons. These photons produce electrical energy by the process known photovoltaic effect. In this paper studies are made to utilization of solar energy to produce electrical energy, for this sun-earth angular relation was found using declination angle of earth based on day number, azimuth angle, altitude angle, angle of incidence for particular location i.e., Andhra university, Visakhapatnam with latitude $17.680^{\circ} \mathrm{N}$ and longitude $83.320^{\circ} \mathrm{E}$. Collecting radiation data for the consider site and calculating actual radiation on tilt surface by applying correction to the data collected. Simulation of solar photovoltaic panel using five parameter model of cell considering top Indian manufactured Solar Panels and estimating output DC power by using location Radiation, temperature and wind as input. Comparing output of simulation with on-line simulators like PV watts and off-line software's SAM, PVs yst. Second part of this paper is estimation of installation cost of solar power plant, cost of generations, Performance ratio, Capacity utilization Factor, LCOE, return of investment, comparing with conventional utility rates.
\end{abstract}

Keywords: Altitude angle; Azimuth angle; Declination angle; Latitude; LCOE; Longitude; PR; PVSYST; PV watts; Radiation data; CUF

\section{Introduction}

Solar Energy is a free source of energy which is very important to all living beings. This intensity of Solar Energy is not continuously available in a particular location as Earth moves around itself and round the Sun in elliptical orbit that varies distance between sun and earth. The axis of rotation Earth is not parallel to the axis of rotation of Sun, because of this the rays of sun sometimes need to travel more distance i.e., need to travel through atmosphere which attenuates the irradiation energy. According to World Radiation Centre (WRC) solar radiation is spectral distribution which was divided in to three sub categories which are Ultraviolet radiation $\lambda \leq 0.38 \mu \mathrm{m}$ the visible radiation 0:38 $\leq \lambda \leq 0: 78 \mu \mathrm{m}$ and the infrared radiation $\lambda \geq 0: 78 \mu \mathrm{m}$ where $\lambda$ is wavelength. The Radiation above the Earth's atmosphere is known as Extra-terrestrial radiations with solar constant $1367 \mathrm{~W} / \mathrm{m} 2$. These solar constants are not constant for the whole year as we send above that distance between sun and earth is not constant [1].

Solar Photovoltaic Power output estimation using Matlab programme requires accurate inputs i.e., radiations data, temperature, wind speed, Solar cell parameters. In this paper the factors studied are proper orientations of solar panel, radiation data collected should be recalculated to get radiation on tilted surface, accurate measurement of parameters of solar cell. Proper orientation of solar photovoltaic surface to make it perpendicular to incident radiation is important to maximize conversion efficiency. For this Sun-Earth angular relations are calculated using different mathematical equations. Normally radiation measurements are made with sensors in a horizontal position as in the case of pyranometer, pyrradiometer or pyrgeometer and at normal incidence when direct solar irradiances are required. But for solar energy application the received surfaces are normally kept in a tilted position to maximize capture of solar energy incident on it. Hence it is necessary to derive the values of radiant energy falling on inclined surface from the values of direct and global solar irradiance. Modelling of solar cells in Matlab requires accurate values of series resistance, shunt resistance, saturation current, ideality factor, photo current. Series resistance of the solar cell consists of several components. Of these components, the emitter and top grid dominates overall series resistance. Shunt resistance of solar cell plays important role in current output. It's value determines recombination's of electron hole pair without passing through the load [2,3].

Electrical Energy is known to be most efficient form of energy which plays important role in industrialization and development. To generate this there are conventional means like thermal power, nuclear power, gas, diesel, etc., which are fossil fuels based power plant and more over they cause pollution and which are in exhaust stage because of this we are in search of alternate energy which are not exhaust and not polluting known as unconventional energy generation like wind, solar, tidal etc., In this paper Solar Energy is considered as source for electrical power generations. Solar photovoltaic panels convert solar energy directly in to direct current electrical energy. The solar photovoltaic panels are made of semiconductor materials i.e., silicon, germanium which when doped with impurities i.e., fifth and third group elements converts into $\mathrm{N}$-type and P-type semiconductor materials. These $\mathrm{N}$-type and P-type materials when sandwiched forms $\mathrm{PN}$ junction which when placed in sun light due to photovoltaic effect i.e., when Photon strike the

*Corresponding author: Nakkela $\mathrm{H}$, Andhra University College of Engineering, Visakhapatnam, Andhra Pradesh, India, Tel:9177018213; E-mail: hari.nakkella@gmail.com Received September 29, 2015; Accepted December 22, 2015; Published January 01, 2016

Citation: Nakkela H (2016) Factors Affecting Solar Photovoltaic Power Output at Particular Location and Cost Estimation. J Electr Electron Syst 5: 166. doi:10.4172/2332-0796.1000166

Copyright: (c) 2016 Nakkela H. This is an open-access article distributed under the terms of the Creative Commons Attribution License, which permits unrestricted use, distribution, and reproduction in any medium, provided the original author and source are credited. 
Citation: Nakkela H (2016) Factors Affecting Solar Photovoltaic Power Output at Particular Location and Cost Estimation. J Electr Electron Syst 5: 166. doi:10.4172/2332-0796.1000166

Page 2 of 7

Photovoltaic module surface creates electron hole pair if we connect two conductors on either side of $\mathrm{P}-\mathrm{N}$ junction and connected to load. These electron hole pairs due electric field at the junction pass through load and thus generate electrical energy. The factor need to be considered is the energy of photon is sufficient to generate electron hole pair. The energy of photon is dependent on wave length of incident radiation. Silicon has affinity of wave length $\lambda \leq 1: 15 \mu \mathrm{m}$. It has energy sufficient to overcome band gap energy of silicon i.e., $1: 121 \mathrm{eV}$. We need to make the surface to orient perpendicular to solar radiation so that the output of photovoltaic panel will be more.

Solar photovoltaic power plant initial cost is higher than any other conventional and non-conventional energy power plants. In India for the year 2015-16 benchmark cost of $1 \mathrm{MW}$ solar photovoltaic plant is 605.85 Lakhs [4]. In this overall cost $55 \%$ cost is on Photovoltaic Modules. Before actually install photovoltaic plant one should first know load profile, retail price of utility, annual amount paid to the utility, location radiation data and environmental conditions of the location, using these one can calculate solar photovoltaic power output at considered locations and cost of generation per of energy, which can be compared with retail price of conventional utility. Solar photovoltaic power plant installed at considered location some useful factors like performance Ratio, capacity utilization factor and levelized Cost of Energy plays important role in estimating feasibility of solar power plant at considered location [5]. For this there some on-line and off-line software's like PVwatts, PVsyst, SAM etc., are available to find and compare above said parameters. In this paper Matlab programme was written to estimate DC power output at considered location by considering modules of Indian

manufactures, location radiation, environmental conditions like temperature and wind speed and multiplying this DC output with overall efficiency other balance of system like cables, mppt tracker, inverter, transformer, soiling losses etc., to know useful AC output energy of the installed plant. Performance Ratio gives insights how efficient the available solar energy is converted into electrical energy. Knowing highest and lowest temperature of location, one can design no of modules of particular rating should be connected in parallel and no. of modules connected in series. As highest temperatures leads to increase of current and lowest temperature leads to increase of voltage.

\section{Sun and Earth Relations}

The Sun position at the location considered i.e., Andhra university, Visakhapatnam, various angles and the relation between incident radiation and surface is explained with help of Figure 1. In order to maximize output from installed photovoltaic power plant, the surface needs to orient perpendicular to rays of sun. This can be possible by proper tracking thesun. To track the sun we need to know two angles Azimuth angle, altitude angle represent in Figures 2 and 3. To find these angles, latitude angle, declination angle, Hour angle, slope of the considered plane, azimuth angle of plane should be known. Latitude angle is location latitude. In this paper location considered is Andhra University, Visakhapatnam $(=17: 68)$ and Figure 4 gives required inclination and azimuth angle of surface. Declination angle changes every day and this can be calculated from the equation of Cooper and other equations are given below section $\mathrm{A}[1,6]$.

\section{Sun-Earth angular relations}

The angular relation of Sun-Earth is given by Figure 4 .

Declination: $(\delta)$
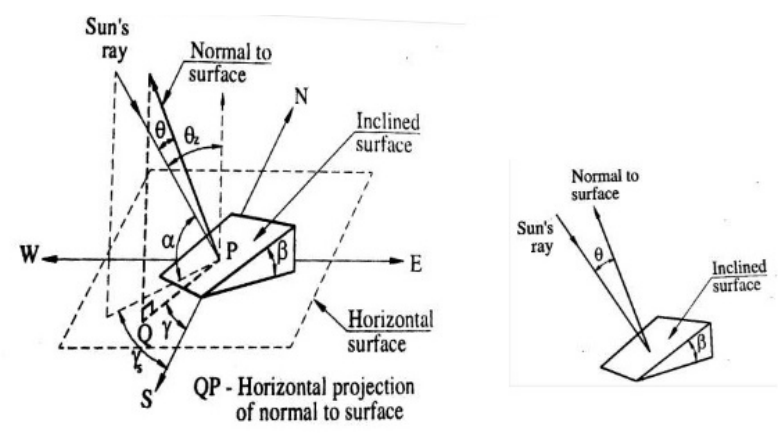

Figure 1: Sun-Earth angular relation.

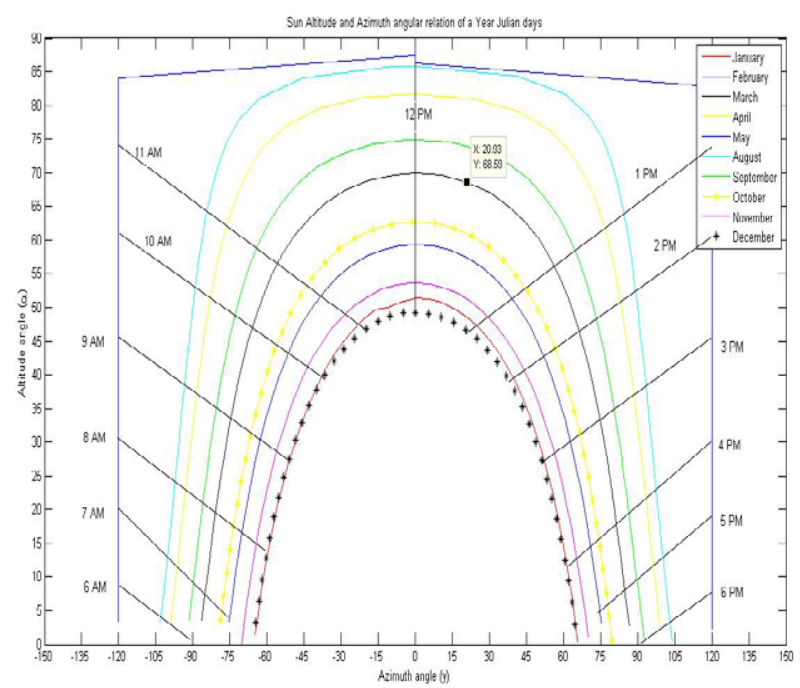

Figure 2: Azimuth angle vs Altitude angle.

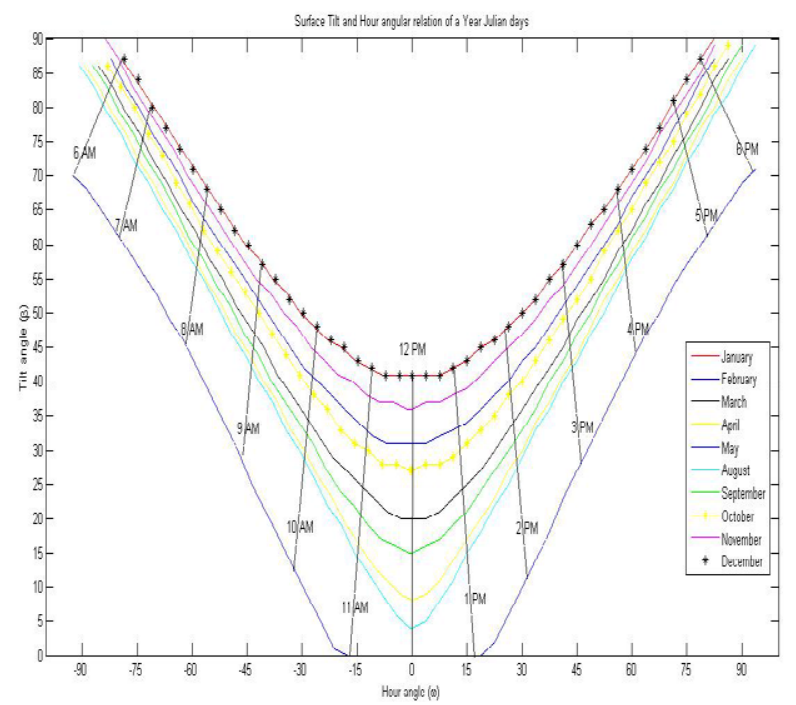

Figure 3: Hour angle vs Slope of surface. 
Citation: Nakkela H (2016) Factors Affecting Solar Photovoltaic Power Output at Particular Location and Cost Estimation. J Electr Electron Syst 5: 166. doi: $10.4172 / 2332-0796.1000166$

Page 3 of 7

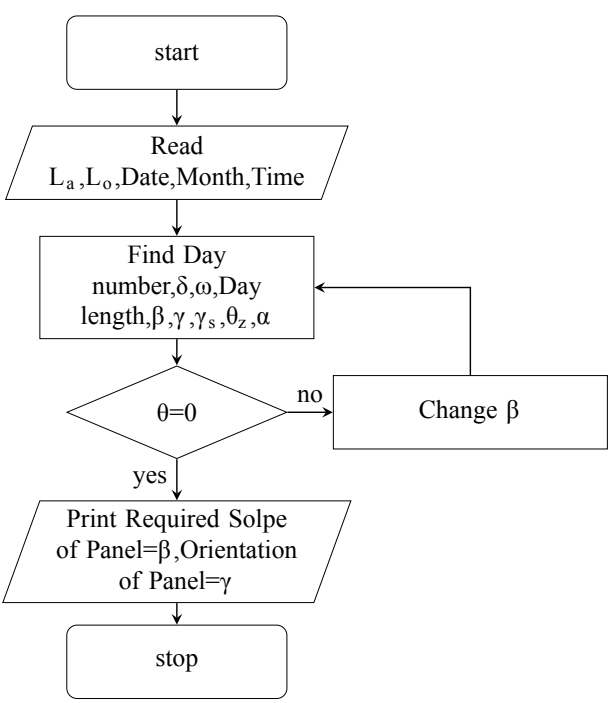

Figure 4: Flow chart to find slope of surface and surface azimuth angle.

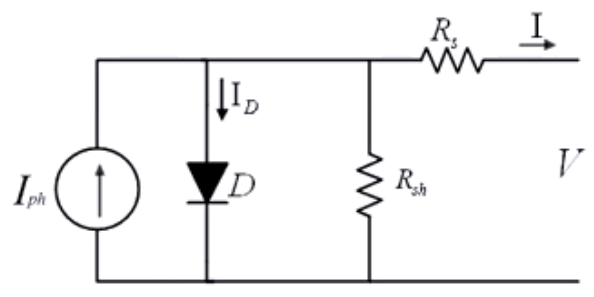

Figure 5: Electrical equivalent circuit of solar cell.

$$
\delta=23: 45 \sin (360(284+\mathrm{n})=365)
$$

Where $\mathrm{n}$ is day number.

Hour Angle $\omega$ The angular displacement of Sun east or west of local meridian as shown in Figure 5 this is due rotation of earth around the sun, 150 of angular displacement per hour, hour angle due east negative and due west is positive. Day Length is given by the equation (2)

$$
D L=\frac{2}{15} \cos ^{-1}(-\tan \phi \tan \delta)
$$

Altitude Angle: $(\alpha)$

The actual location of sun in the sky at particular place and time is given by equation (3)

$$
\alpha=\sin ^{-1}(\sin \phi \sin \delta+\cos \phi \cos \delta \cos \omega)
$$

Azimuth angle: $(\gamma)$

The surface azimuth of plane should track sun azimuth angle which is given by the equation (4)

$$
\gamma=\sin ^{-1}(\cos \delta \sin \omega / \sin \alpha)
$$

Incident Angle $(\theta)$

The angle of incidence of solar rays on plane of surface considered should be perpendicular to it and should be parallel to perpendicular drawn to the considered surface. This incidence angle is given by (5)

$$
\theta=\cos ^{-1}\left(\cos \theta_{z} \cos \beta+\sin \theta_{z} \sin \beta\left(\gamma_{s}-\gamma\right)\right)
$$

Where

$\theta_{z}$ is Zenith angle

$\gamma_{s}$ is Sun Azimuth angle

$\gamma$ is Surface Azimuth angle

Zenith angle $\left(\theta_{z}\right)$

The of Sun rays subtend an angle with respect to the Polar axis of earth is known as Zenith angle. It can be from the below equation (6)

$$
\theta_{z}=\cos ^{-1}(\cos \phi \cos \delta \cos \omega+\sin \phi \sin \delta)
$$

\section{Necessary corrections to available radiation data of considered location}

Solar Radiation data which is divided into three major groups i.e., direct or beam radiation, diffuse radiation, Total solar Radiation. Total solar radiation is sum of direct, diffuse, terrestrial radiation. Solar Radiation data plays a vital role in estimating electrical power output from the installed capacity if we want to simulate by using software, the radiation data which can be obtained from IMD on payment basis which is horizontal data need to be corrected if the considered plane is tilt with some angle. Here considered IMD's relations and

Mani's relations are consider to find total solar radiation which are obtained from the report Solar Radiant Energy over India [7].

Relationships given by IMD: The Total Solar Radiation $G_{T}$ falling on inclined surface has three components. They are direct solar radiation or Beam $G_{B}$, diffuse solar radiation $G_{D}$ and reflected solar radiation $G_{R}$ which are measured in $\mathrm{W} / \mathrm{m}^{2}$ i.e., Power, if we integrate for specific time then in $\mathrm{J} / \mathrm{m}^{2}$ i.e., Energy.

$$
\mathrm{G}_{\mathrm{T}}=\mathrm{G}_{\mathrm{B}}+\mathrm{G}_{\mathrm{D}} \downarrow+\mathrm{G}_{\mathrm{R}} \uparrow
$$

Beam Radiation $G_{B}$ of Inclined surface is given by $G_{B H}$ which is beam radiation on horizontal surface.

$$
\mathrm{G}_{\mathrm{B}}=\mathrm{G}_{\mathrm{BH}}\left(\cos \theta / \cos \theta_{\mathrm{z}}\right)
$$

Mani's Relation Ship between global solar radiation on horizontal surface and global solar radiation on horizontal surface. Tilt Factor: $\mathrm{K}_{\mathrm{I}}$

$$
\begin{aligned}
& K_{I}=\left(G_{T} \downarrow / G \downarrow\right) \\
& K_{I}=\cos \beta+\frac{\sin \beta \cos \left(\gamma_{s}-\gamma\right)}{\tan \alpha}
\end{aligned}
$$

Where $G$ is Global Solar Radiation on Horizontal Surface $G_{T}$ is Total Solar Radiation on tilted Surface $G_{D}$ is diffuse solar radiation on horizontal surface $\beta$ is inclination angle of surface

\section{Extraction of Electrical Parameters of Solar Cell}

The solar modules are direct current electrical generators in solar photovoltaic power plant. To estimate electrical output from the considered solar photovoltaic power plant using software's as the direct installation is costly, as manufacturing cost is more. So, before installing solar photovoltaic power plant in a particular location one must be aware of meteorological data of the location which plays very important role in electrical output from the installed plant and the required meteorological data is Radiation data, Wind speed, Temperature which affects the electrical parameters of solar modules. The electrical parameters of solar modules are photo

Current $\mathrm{I}_{\mathrm{ph}}$, Dark saturations current $\mathrm{I}_{\mathrm{o}}$, Ideality Constant A, Series 
Citation: Nakkela H (2016) Factors Affecting Solar Photovoltaic Power Output at Particular Location and Cost Estimation. J Electr Electron Syst 5: 166. doi: $10.4172 / 2332-0796.1000166$

Page 4 of 7

resistance $R_{s}$, Shunt Resistance $R_{p}[2,8]$. These electrical parameters which are not present in the data sheet given by manufacturer so we need find these parameters in order to estimate electrical output from the consider module at particular location i.e., Radiation, Temperature and Wind speed.

\section{Solar photovoltaic module: Data sheet terminology}

The solar photovoltaic module is made of Ns cells connected in series and $\mathrm{Np}$ series strings connected in parallel. Thus formed solar photovoltaic module is Electrical DC generator using solar radiation as input is current source. The current is obtained by the photons of light which when fall on the module creates electron-hole pairs this effect is known as photovoltaic effect, which are allowed to flow through the load connected across the module. The flow of electrons through load is possible because electric field created across the junction of each cell because each photovoltaic cell is a diode which forms by combining P-type and N-type material, each diode has breakdown voltage of around 0.6-0.8 (V). Thus voltage of each cell when combines in series in module adds up to form module voltage. From the data sheet of considered photovoltaic module we get Maximum power $\mathrm{P}_{\mathrm{mp}}$, open circuit voltage $\mathrm{V}_{\mathrm{oc}}$, short circuit $\mathrm{I}_{\mathrm{sc}}$, maximum power point voltage $\mathrm{V}_{\mathrm{mp}}$, maximum power point current $\mathrm{I}_{\mathrm{mp}}$, efficiency of module $\eta_{m}$, at STC conditions i.e., $\mathrm{G}_{\mathrm{n}, \mathrm{T}}=\mathrm{at} 1000 \mathrm{~W} / \mathrm{m}^{2}, \mathrm{~T}_{\mathrm{a}}=\mathrm{T}_{\mathrm{c}}=298 \mathrm{~K}$, air mass 1.5 , wind speed $\mathrm{W}_{\mathrm{i}}=1 \mathrm{~m} / \mathrm{s}$, and as well as at NOCT condition i.e., at $\mathrm{G}_{\mathrm{T}, \mathrm{NOCT}}=800$ $\mathrm{W} / \mathrm{m}^{2}, \mathrm{~T}_{\mathrm{NOCT}}=293 \mathrm{~K}$, air mass 1.5 , wind speed $\mathrm{W}_{\mathrm{i}}=1 \mathrm{~m} / \mathrm{s}$. Temperature coefficients of Short circuit current $\kappa I_{S C}$, Open circuit Voltage $\kappa V_{O C}$, Maximum Power Point $\kappa P_{m p}$, No. of Cells in series and parallel, area of cell and module, weight of the module. By using these values we need to find the above said electrical parameters of considered module to accurately estimate electrical output from the module at particular location and climatic conditions.

\section{Mathematical equations}

Electrical parameters of considered solar module as mention above are combine to form basic equation as show below which are obtained from equivalent electrical circuit of solar cell and applying KCL to the circuit

$$
\begin{aligned}
& I_{o}=I_{o, n}\left(\frac{T_{c}}{T_{a}}\right)^{3} \exp \left[\frac{q E_{g}}{A_{k}}\left(\frac{1}{T_{a}}-\frac{1}{T_{c}}\right)\right] I=I_{p h}-I_{0}\left(\exp \left(\frac{V+I R_{S}}{A V_{t}}\right)-1\right)-\frac{V+I R_{S}}{R_{p}} \\
& V_{t}=N_{S} k T_{c / q} \\
& I_{p h}=\frac{G_{T}}{G_{n, T}}\left[I_{s c}+\kappa I_{S C}\left(T_{c}-T_{a}\right)\right] \\
& I_{o, n}=\frac{I_{S C}}{\exp \left(\frac{V_{o c}}{A V_{T, n}}\right)-1} \\
& I_{o}=I_{o, n}\left(\frac{T_{c}}{T_{a}}\right)^{3} \exp \left[\frac{q E_{g}}{A_{k}}\left(\frac{1}{T_{a}}-\frac{1}{T_{c}}\right)\right]
\end{aligned}
$$

Thermal Voltage at particular cell temperature

After seeing these equations we came to know out off five unknown variables we can find two variables $\mathrm{I}_{\mathrm{ph}}, \mathrm{I}_{0}$ and other three variables need to be calculated those are $\mathrm{R}_{\mathrm{s}}, \mathrm{R}_{\mathrm{p}}, \mathrm{A}$. Out of these three $\mathrm{A}$ which is ideality constant of diode is taken the value between $1 \leq A \leq 2$. To get $\mathrm{R}_{\mathrm{s}}$ and $\mathrm{R}_{\mathrm{p}}$ we need substitute points $\left(\mathrm{V}_{\mathrm{oc}}, 0\right)$ open circuit condition, $\left(0, \mathrm{I}_{\mathrm{sc}}\right)$ short circuit condition, $\left(\mathrm{V}_{\mathrm{mp}}, \mathrm{I}_{\mathrm{mp}}\right)$ maximum power point condition which we can obtain from data sheet and solve the equation numerically to get unknown variable and this process is trial and error because here $A$ is assumed, final values of unknown variables can be obtained by observing $\mathrm{V}_{\text {vs }} \mathrm{I}$ and $\mathrm{V}_{\text {vs }} \mathrm{P}$ characteristics of the module using Matlab program. The minimum and maximum values of $R_{s}$ and $R_{p}$ are obtained respectively using below equations [9].

$$
\begin{aligned}
& R_{s, \text { max }}=\frac{V_{o c}-V_{m p}}{\mathrm{I}_{\mathrm{m} p}} \\
& R_{p, \text { min }}=\frac{V_{m p}}{I_{S C}-\mathrm{I}_{\mathrm{m} p}}-\frac{V_{o c}-V_{m p}}{\mathrm{I}_{\mathrm{m} p}}
\end{aligned}
$$

Finding cell temperature of module which is different from ambient temperature which plays important role in simulating electrical output from the photovoltaic module which was designed in Matlab/Simulink. The relation between cell and ambient temperature is given by the below equation.

$$
\begin{aligned}
& T_{c}=T_{a}+\frac{0.32}{\left(8.91+2 W_{i}\right)} G_{T} \\
& \text { Or } \\
& T_{c}=T_{a}+\left(1-\frac{\eta_{m}}{\Gamma \psi}\right) G_{T}\left(\frac{\Gamma \psi}{v_{L}}\right)
\end{aligned}
$$

where $\Gamma$ is transmittance of cover over cell $\psi$ is fraction of radiation incident on the surface to the observed $v_{L}$ is loss coefficient i.e., by convection and radiation from the surface

$$
\frac{\Gamma \psi}{v_{L}}=\left(T_{c, N O C T}-T_{a}\right) / G_{T, N O C T}
$$

\section{Data sheet values of different solar modules}

From the below data sheet values given in Tables 1 and 2 and numerical analysis using Matlab program given by Figure 6 and comparing with $\mathrm{I}-\mathrm{V}, \mathrm{P}-\mathrm{V}$ characteristics of data sheet and plot obtained from program written in Matlab accurate values of $A, R_{s}$ and $\mathrm{R}_{\mathrm{p}}$ are tabulated below Table $3-\mathrm{A} 2$ as $\mathrm{I}_{\mathrm{ph}}$ and $\mathrm{I}_{\mathrm{o}}$ varies with radiation, Temperature of the cell which depends on ambient temperature and wind speed [10].

\section{Meteorological data and electrical energy output estimation}

Meteorological data which plays important role in estimating electrical output from solar photovoltaic power plant which was not installed but simulated using Matlab/Simulink software. In this paper

\begin{tabular}{|c|c|c|c|c|}
\hline Parameters & Tata Solar & Titan Solar & Vikram Solar & Surana solar \\
\hline Pmp W & 250 & 250 & 250 & 250 \\
\hline Voc V & 37. & 37.80 & 37.45 & 37.8 \\
\hline lac A & 8.71 & 8.63 & 8.70 & 8.63 \\
\hline Vmp V & 30.2 & 30.72 & 30.58 & 30.72 \\
\hline Imp V & 8.3 & 8.14 & 8.18 & 8.14 \\
\hline $\mathrm{nm}$ & 0.15 & - & 0.153 & - \\
\hline Ns & 60 & 60 & 60 & 60 \\
\hline ĶPmp & -1.095 & -1.075 & -1.025 & -1.025 \\
\hline ĶV oc & -0.123 & -0.120 & -0.116 & -0.120 \\
\hline Ķlsc & 0.0055 & 0.00345 & 0.00504 & 0.00345 \\
\hline Area m ${ }^{2}$ & 1.460 & 1.460 & - & 1.460 \\
\hline TcNOCT K & 320 & 318 & 318 & - \\
\hline Bipass Diodes & - & 3 & 3 & 3 \\
\hline
\end{tabular}

Table 1: Data sheet values of different manufactures at stc. 
Citation: Nakkela H (2016) Factors Affecting Solar Photovoltaic Power Output at Particular Location and Cost Estimation. J Electr Electron Syst 5: 166. doi:10.4172/2332-0796.1000166

Page 5 of 7

\begin{tabular}{|c|c|c|c|}
\hline Parameters & Photon Solar & Jupiter solar & EMMVEE solar \\
\hline Pmp W & 250 & 250 & 250 \\
\hline Voc V & 43.06 & 37.0 & 37.62 \\
\hline lac A & 7.74 & 8.87 & 8.76 \\
\hline Vmp V & 36.07 & 30.5 & 29.76 \\
\hline Imp V & 6.93 & 8.3 & 8.40 \\
\hline $\mathrm{nm}$ & 0.129 & 0.16 & 0.154 \\
\hline $\mathrm{Ns}$ & 72 & 60 & 60 \\
\hline ĶPmp & -1.075 & -1.05 & -1 \\
\hline ĶV oc & -0.142 & -0.1073 & -0.127 \\
\hline Ķlsc & 0.00448 & 0.00354 & 0.00438 \\
\hline Area m & 1.752 & - & 1.46 \\
\hline TcNOCT K & - & 318.5 & 319 \\
\hline Bipass Diodes & - & - & 3 \\
\hline
\end{tabular}

Table 2: Data sheet values of different manufactures at stc.

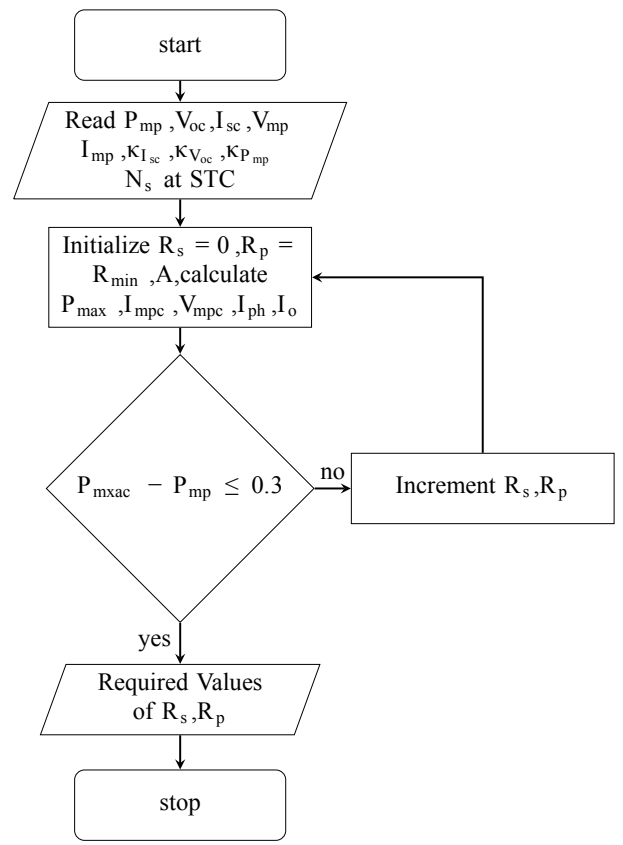

Figure 6: Flow chart to find five parameters of solar cell.

\begin{tabular}{|l|c|c|c|}
\hline Manufacturer & Idelity constant A & Rs $\boldsymbol{R}$ & Rp $\boldsymbol{\Omega}$ \\
\hline TATA Solar & 1.3 & 0.1165 & 1444.9 \\
\hline Vikram Solar & 1.154 & 0.2 & 810 \\
\hline Titan Solar & 1.14 & 0.23 & 1290 \\
\hline Surana Solar & 1.138 & 0.23 & 1176 \\
\hline Photon Solar & 1.64 & 0 & 919.905 \\
\hline Jupiter Solar & 1.52 & 0.3 & 875 \\
\hline EMMVEE Solar & 1.2 & 0.23 & 1449 \\
\hline
\end{tabular}

Table 3: Calculated electrical parameters of different modules.

author considered data of Radiation on tilt surface with tilt angel of $\beta=17.7$ because it gives maximum output for fixed mounting of solar photovoltaic module. This data consists of monthly average daily hourly average instantaneous radiations, temperature, wind speed from year 1986-2000 [7] and comparing with meteorological data collected for month April 2015 [11] at considered location and comparing simulation results electrical energy output for month April and total year using above data from installed $110.25 \mathrm{KW}$ solar photovoltaic power plant. The yearly electrical energy output at particular location is compared with other software's like PVsyst, SAM, PVwatts and with program developed in this paper values given in Tables 4-6 [12].

\section{Cost Estimation}

Solar Photovoltaic Power Plant installation is more costly compare to conventional power plants like Thermal, nuclear, Gas and Oil. But operating cost of solar photovoltaic power is negligible compare to conventional power plants. More over there is no pollution and hence known as green power. By proper sizing and selecting location with care can make comparison cost of energy generation from solar plant with conventional power plants. Electrical Energy generated from the solar power plant is not continuous and thus limits to replace conventional power plants. From Table 7 it was known that considered load consumes $16,57,614$ units of electrical energy per year, hourly demand of load is not known as the load is educational institute it works for 10 hours a day and with working days around 240 working days, per day energy consumption on an average is around 6906.72 units, per hour around 690.67 units. To generate 690.67 units per hours solar photovoltaic power plant capacity should be around 1.5 MW, by considering energy output from $1 \mathrm{KW}$ is around 4.8-5.13 units per day at considered location i.e., Andhra university, Visakhapatnam. Initial cost is more and more over educational institutes will get $30 \%$ subsidy on $100 \mathrm{KW}$ solar photovoltaic power plant from government of India [13,14]. To estimate cost of electrical energy per unit we need to know solar photovoltaic power plant equipment used and there cost. According to Government of India bench mark cost for $1 \mathrm{MW}$ solar photovoltaic power plant for the year 2015-2016 is Rs 605.85 Lakhs. Which include Photovoltaic Modules, Land cost, civil and general works, mounting structures, Power conditioning unit, Cables and Transformers, Preliminary and Pre-operative Expenses. Photovoltaic panel costs around $55 \%$ of total cost so one must be careful in choosing

\begin{tabular}{|l|c|}
\hline Source & Electrical Energy Output \\
\hline Matlab data (1986-2000) & $20395 \mathrm{KWh}$ \\
\hline Matlab data (April 2015) & $17605 \mathrm{KWh}$ \\
\hline PVwatts & $17444 \mathrm{KWh}$ \\
\hline PVsyst & $17130 \mathrm{KWh}$ \\
\hline SAM & $18320 \mathrm{KWh}$ \\
\hline
\end{tabular}

Table 4: Electrical energy produced from $110.25 \mathrm{kw}$ for the month April of considered location.

\begin{tabular}{|l|c|}
\hline Source & Electrical Energy Output \\
\hline Matlab & $159818 \mathrm{KWh}$ \\
\hline PVwatts & $175266.32 \mathrm{KWh}$ \\
\hline PVsyst & $179770 \mathrm{KWh}$ \\
\hline SAM & $195724 \mathrm{KWh}$ \\
\hline
\end{tabular}

Table 5: Electrical energy produced from $110.25 \mathrm{kw}$ for year of considered location.

\begin{tabular}{|l|c|c|c|}
\hline Year & Rs/KVAh & Rs/KVA & Bill paid (Rs) \\
\hline $2013-14$ & 6.90 & 350 & - \\
\hline $2014-15$ & 6.90 & 350 & $1,52,58,163$ \\
\hline $2015-16$ & 7.31 & 371 & - \\
\hline
\end{tabular}

Table 6: Tariff per kvah paid to conventional utility.

\begin{tabular}{|l|c|c|c|}
\hline Year & MD(KVA) & Units(KVAh) & Rs/KVAh \\
\hline $2014-15$ & $650.46(700)$ & 1657614 & 9.204 \\
\hline
\end{tabular}

Table 7: Yearly electrical energy consumed by considered load. 
Citation: Nakkela H (2016) Factors Affecting Solar Photovoltaic Power Output at Particular Location and Cost Estimation. J Electr Electron Syst 5: 166. doi:10.4172/2332-0796.1000166

Page 6 of 7

\begin{tabular}{|l|c|c|}
\hline KVAh generated & Total Cost(Rs) & Rs/KVAh \\
\hline 3579930 & 11754295 & 3.8 \\
\hline
\end{tabular}

Table 8: Life time energy output from installed $110.25 \mathrm{kw}$ Solar Photovoltaic power plant.

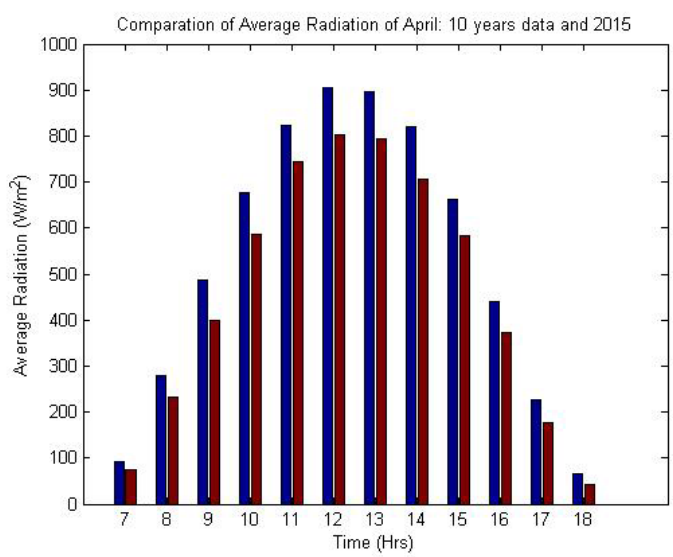

Figure 7: Average radiation data of month April.

photovoltaic panes. From the above benchmark cost for $1 \mathrm{MW}$ we can estimate cost for 110: $25 \mathrm{KW}$ i.e., around Rs 58.733 lakhs. Now in this paper, considered load College of Engineering, Andhra University which consumes electrical energy as shown in Table 8 [15-17].

\section{Factors Determining Solar Plant Feasibility}

Performance Ratio, Capacity Utilization Factor, LCOE are important factors to compare photovoltaic power plant with conventional power plants [18]. Performance Ratio is the ratio of energy generated or measured to energy modelled. This parameter is used to compare the actual plant performance which used to rectify fault which decrease energy output from the installed system.

$$
\mathrm{PR}=\frac{\text { EnergyMeasured }}{\text { EnergyModelled }}
$$

Capacity Utilization Factor is the ratio energy output from installed system to the energy it would have generated if the system is available for 24 hours and 365 days. LCOE $=\frac{\text { Toatal Life cycle Energy generated }}{\text { Initialcost }+\mathrm{O} \& \text { Mcost }}$

$$
\text { CUF }=\frac{\text { Energy Measured }}{\text { Capacity of Plant } * 8760}
$$

Levelized Cost of Electricity is used to compare cost per unit of non-conventional system with conventional system. It is the ratio of total life cycle cost to total lifetime energy production. Total life cost includes initial cost, operation and maintenance cost.

$$
\text { LCOE }=\frac{\text { Toatal Life cycle Energy generated }}{\text { Initialcost }+\mathrm{O} \& \text { Mcost }}
$$

From Table 7 it is known how much money paid by the consumer to the utility and units consumed by considered Load. If for the considered load 110.25 KW solar photovoltaic power is installed, in this paper comparison was made between retailer price and renewable energy source unit price [19]. To calculate cost of generation of one unit electrical energy from the installed load and payback period, Performance ratio and capacity utilization factor of installed solar

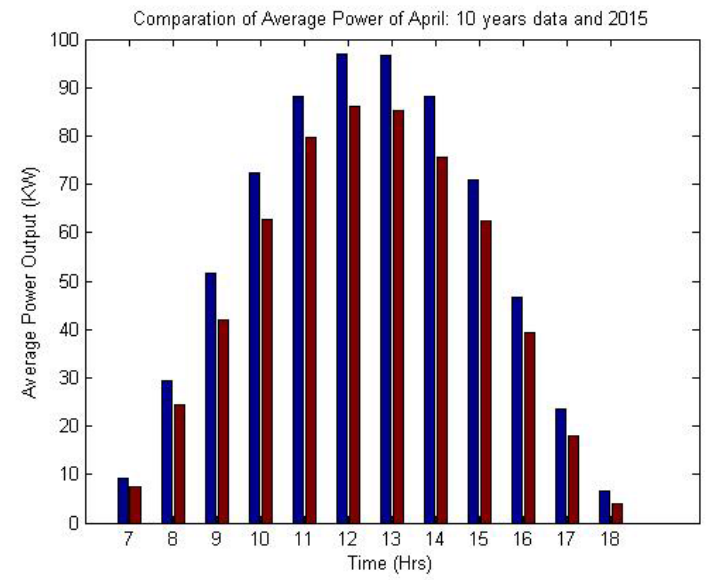

Figure 8: Comparison of power output for month April using 1986-2000 data and 2015 April data.

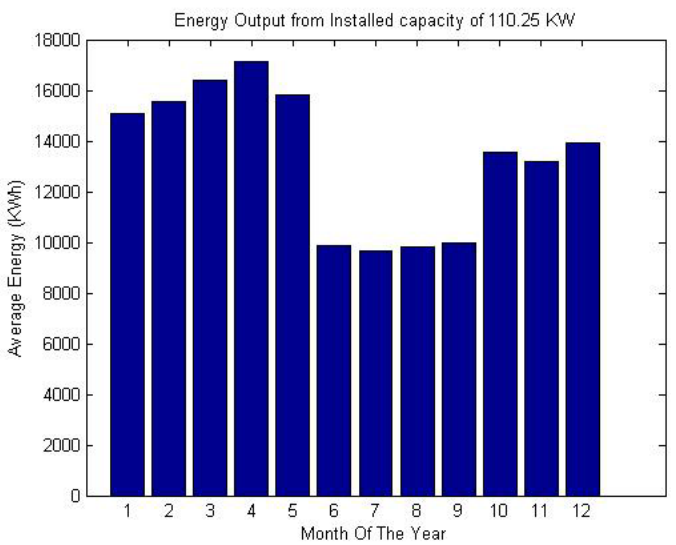

Figure 9: Estimating electrical energy output from $110.25 \mathrm{kw}$ solar PV system using 1986-2000 data.

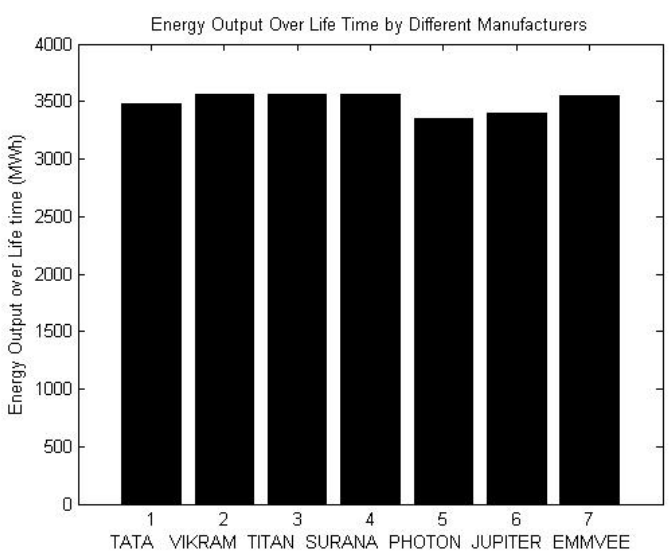

Figure 10: Energy output by using modules of different manufacturers.

photovoltaic plant. Solar photovoltaic power life time is considered 25 years in which it yields $90 \%$ of electrical energy for first 10 years and then up to 25 years it yields about $80 \%$ comparing with first years 
Citation: Nakkela H (2016) Factors Affecting Solar Photovoltaic Power Output at Particular Location and Cost Estimation. J Electr Electron Syst 5: 166. doi:10.4172/2332-0796.1000166

Page 7 of 7

output. Operation and maintenance cost will be around Rs 1.3 lakhs $[20,21]$.

\section{Conclusion}

Estimation of electrical power output from Solar Photovoltaic Power Plant at particular location using Matlab programme requires accurate calculation of five parameters of solar cell, calculation of radiation data on tilted surface and knowing location temperature and wind speed (Figures 7-10). In this paper 110.25 KW solar photovoltaic power plant is considered and using radiation data of Visakhapatnam from year (1986-2000) and radiation data of the month April 2015 to calculate AC energy output and compare these results with PVwatts, PVsyst, SAM. The calculated values of LCOE is $3.8 \mathrm{Rs} / \mathrm{KVAh}$ given in Table 5 if plant operates for 25 years and first year energy Production was $159818 \mathrm{KVAh}$ and for 25 years the energy output is $3579930 \mathrm{KVAh}$.

\section{Reference}

1. Duffie JA, Beckman WA (2013) Solar Engineering of Thermal Processes (2nd edn). New York.

2. Sulaiman SA, Hussain HH, NikLeh NSH, Razali MSI (2011) Effects of Dust on the Performance of PV Panels. World Academy of Science, Engineering and Technology 5: 2028-2033.

3. Skoplaki E, Boudouvis AG, Palyvos JA (2008) A simple correlation for the operating temperature of photovoltaic modules of arbitrary mounting. Solar Energy Materials and Solar Cells 92:1393-1402.

4. Green MA (1982) Solar cells: operating principles, technology and system applications. Prentice-Hall, Inc., Englewood Cliffs, NJ, USA.

5. Cambell M (2008) The Drivers of the Levelized Cost of Electricity for UtilityScale Photovoltaics. Sun Power.

6. Solar Radiation Monitoring Laboratory, University of Oregon.

7. Tyagi AP (1988) Solar Radiant Energy Over India. Indian Meteorological Department, India.
8. Shongwe S, Hanif M (2015) Comparative Analysis of Different Single-Diode PV Modeling Methods. IEEE Journal of Photovoltaics 5: 938-946.

9. Villalva MG, Gazoli JR, Filho ER (2009) Comprehensive Approach to Modeling and Simulation of Photovoltaic Arrays. IEEE Transactions On Power Electronics 24: 1198-1208.

10. Sera D, Teodorescu R, Rodriguez P (2007) PV Panel model based on datasheet values. IEEE 2392-2396.

11. http://www.imdaws.com/ViewRadiationData.aspx.

12. Kandasamy CP, Prabu P, Niruba K (2013) Solar Potential Assessment Using PVSYST Software. IEEE 667-672.

13. Solar (2012) Government of India, Ministry of New and Renewable Energy.

14. New \& Renewable Energy Development Corporation of Andhra Pradesh (NREDCAP).

15. Central Electricity Regulatory Commission (2015) CERC, New Delhi.

16. Gan CK, Tan PH, Khalid S (2013) System Performance Comparison Between Crystalline and Thin-Film Technologies under Different Installation Conditions. IEEE Conference on Clean Energy and Technology 362-367.

17. Ahmed MM (2003) Design and Proper Sizing of Solar Energy Schemes for Electricity Production in Malaysia. National Power and Energy Conference (PECon) Proceedings 268-271.

18. Singh VP, Ravindra B, Vijay V, Bhatt MS (2014) A comparative performance analysis of C-Si and A-Si PV based rooftop grid tied solar photovoltaic systems in Jodhpur. 3rd International Conference On Renewable Energy Research And Applications 250-255.

19. Endo E, Kurokawa K (1994) Sizing Procedure For Photovoltaic Systems. IEEE 1:1196-1199.

20. Zolkapli M, Al-Junid SAM, Othman Z, ManutA, MohdZulkifli MA (2013) HighEfficiency Dual-Axis Solar Tracking Developement using Arduino. International Conference on Technology, Informatics, Management, Engineering and Environment 23-26.

21. Bajpai $P$, Kumar S (2011) Design, Development and Performance Test of an Automatic Two-Axis Solar Tracker System. India Conference (INDICON), 2011 Annual IEEE 1-6. 